\title{
ESSENTIAL OIL COMPOSITION AND PHYTOTOXICITY EFFECTS OF SOLANUM NIGRUM L. ON SEED GERMINATION OF SOME VEGETABLES
}

\author{
Afolayan, A. J. ${ }^{*}$ - BVENURA, C. \\ MPED Research Center, University of Fort Hare \\ P Bag X1314, Alice 5700, South Africa \\ *Corresponding author \\ e-mail: aafolayan@ufh.ac.za; phone: +27-40-602-2323; fax: +27-86-628-2295 \\ (Received 28 ${ }^{\text {th }}$ Feb 2017; accepted $19^{\text {th }}$ May 2017)
}

\begin{abstract}
The allelopathic activities of Solanum nigrum shoot and root aqueous extracts on cabbage, spinach and tomato seed germination were investigated. Treatment concentrations were $0,2,4,6,8$ and $10 \mathrm{mg} \mathrm{ml}^{-1}$. The results indicate that the shoot extracts did not affect the germination of tomato and spinach seeds but $2 \mathrm{mg} \mathrm{ml}^{-1}$ slightly hindered the germination of cabbage seeds. The highest root extract concentration $\left(10 \mathrm{mg} \mathrm{ml}^{-1}\right)$ led to a significantly lower germination percentage in tomato seeds in comparison with the control. The highest extract concentration $\left(10 \mathrm{mg} \mathrm{ml}^{-1}\right)$ in both shoot and root extracts slowed down germination time in tomato seeds. The mean germination time indicates that cabbage seeds germinated faster than tomato and onion. These results indicate that $S$. nigrum shoot and root extracts pose no hindering effect on the germination of cabbage and onion seeds, although increased root extract concentrations may hinder germination in tomato seeds. A total of 16 and 12 compounds were respectively identified from the shoots and roots of Solanum nigrum analysed by GC-MS. The major shoot compositions were Citronellol (11.98\%), Cyclohexanol, 2-methyl-5-(1-methylethenyl) (5.84\%), Geraniol (3.76\%) and Geranyl tiglate (3.53\%). In the roots, Hexacosane (35.62\%), 1H-Indole, 1methyl-2-phenyl (12.66\%), Hexadecanal $(8.11 \%)$ and Tetrasiloxane, decamethyl $(7.58 \%)$ were the major components.
\end{abstract}

Keywords: allelopathy, wild vegetable, seed viability, chemical compositions, GC-MS

\section{Introduction}

The domestication of wild vegetables as a means of combatting food insecurity has been a topic of interest in South Africa for over a decade. Various aspects of wild vegetables have been widely documented including their agronomy and more commonly their nutritional compositions (Edmonds and Chweya, 1997; Odhav et al., 2007; Flyman and Afolayan, 2008; Atta et al., 2010; Mahala et al., 2012). Although the cultivation of wild vegetables for food is common in some African countries such as Botswana, Nigeria, Ghana, Zambia and Zimbabwe, this practice is not widespread in South Africa (Gbile et al., 1988; Mushita, 1997; Madisa and Tshamekang, 1997; Maroyi, 2011; Aju et al., 2013). Since wild vegetables are commonly viewed as weeds, intercropping them with conventional crops and/or vegetables is one of the options that need to be explored in order to make maximum use of the land in the fight against food insecurity. However, there are fears that wild vegetables may cause growth problems or nutritional stress to exotic vegetables growing alongside them.

The stimulatory or inhibitory effects plants have on the growth of other plants within the same ecosystem through a mechanism known as allelopathy is well known. Biochemicals known as allelochemicals/allelochems are released from plant parts by leaching, root exudation, volatilisation, residue decomposition and other processes in both natural and agricultural systems (Fraenkel, 1959; Stamp, 2003). The 
allelochemicals are secondary metabolites like terpenoid and phenolic compounds such as flavonoids, anthocyanins, lignin as well as tannins and these have specific actions (Khanh et al., 2007). In recent years, there have been interests in the allelopathic activities of wild plants. Ataollahi et al. (2014) reported that increasing the concentration of the Eucalyptus globulus leaf extract had a strong allelopathic effect on $S$. nigrum seed germination, shoot and root length growth. In another study, Sadeghi et al. (2010) reported that the water extract of Helianthus annuus inhibited the germination of $S$. nigrum seeds. The roots of Tithonia diversifolia have been found to stimulate the growth and chlorophyll content of some Solanum species (Otusanya et al., 2014). Sabh and Ali (2010) found S. nigrum extracts to hinder dicotyledonous seedling growth and chlorophyll in comparison with monocotyledonous seeds. S. nigrum has also been reported to reduce germination, root and shoot length growth of onion (Baličević et al., 2015). Some allelochemicals such as alkaloids that are produced by $S$. nigrum have been found responsible for suppressing growth of other plants (Sabh and Ali, 2010).

Although S. nigrum is an important wild vegetable of the Eastern Cape Province, its allelopathic activity on some important vegetables has not been investigated. Cultivating wild vegetables alongside traditional vegetables in farming operations is an option being explored in order to reduce food insecurity. The current experiment was therefore conducted to investigate the effect of $S$. nigrum root and shoot aqueous extracts on the germination of cabbage, spinach and tomato seeds. Understanding plant on plant interactions is important in agricultural production especially in relation to intercropping. The detrimental effects of inclusion of wild vegetables into the existing farming operation on the ecology, environmental degradation and conservation of genetic biodiversity require a better understanding. This study was therefore conducted to help know the stimulatory or inhibitory effects of the residues of S. nigrum on the germination of these important traditional vegetables. Also, a comprehensive understanding of the essential oil composition of $S$. nigrum is vital for proper understanding of its value as both a nutritional and pharmacological plant. The essential oils of the fresh roots and shoots were therefore also analysed for their chemical compositions.

\section{Materials and methods}

\section{Plant collection}

S. nigrum plant samples were previously identified in 2011 at the University of Fort Hare and the voucher specimen (BVE 11/017) kept at the Giffen herbarium. Fresh samples were collected by uprooting the whole plant from around Alice in August 2015 in the wild and washing with distilled water to remove impurities. Cabbage (Starke Ayres - Cabbage: Drumhead), tomato (Starke Ayres- Hybrid Tomato: STAR 9003) and spinach (Starke Ayres - Swiss Chard: Fordhook Giant) seeds were purchased from a local supermarket.

\section{Preparation of aqueous extracts}

The method of Badmus and Afolayan (2012) was used to prepare the extracts of the plant samples. The root and shoot samples were separately dried to a constant weight in the oven at $35^{\circ} \mathrm{C}$. The dry matter yields were ground in an electric hammer mill fitted with $1 \mathrm{~mm}$ sieve and stored separately in tightly sealed vial bottles in the refrigerator at 
$4^{\circ} \mathrm{C}$ till further use. About $50 \mathrm{~g}$ of each powdery material was extracted in $1.5 \mathrm{~L}$ of distilled water and agitated on an orbital shaker for $12 \mathrm{~h}$ at room temperature. The filtrate was freeze dried at $-50^{\circ} \mathrm{C}$ under the vacuum (RVT4104, USA) and reconstituted in distilled water to obtain the desired concentrations of 10, 8, 6, 4 and $2 \mathrm{mg} \mathrm{ml}^{-1}$.

\section{Viability test}

Viability tests were conducted using the Tetrazolium Chloride Technique. Following the method described by Peters (2000), 25 seeds were imbibed in water overnight at $22.5 \pm 2.5^{\circ} \mathrm{C}$ in triplicates. The seeds were then cut along the margin without damaging the embryo and soaked in colourless $0.1 \%$ solution of 2,3,5- triphenyltetrazolium chloride (TTC) for $24 \mathrm{~h}$ at $22.5 \pm 2.5^{\circ} \mathrm{C}$ in the dark. The $\mathrm{pH}$ of the TTC solution was 6.61. The seeds were removed from the TTC solution, washed in distilled water and soaked in $95 \%$ ethanol to permit direct observation of the embryo under the microscope. Embryos of viable seeds appeared reddish in colour.

\section{Seed germination trials}

To evaluate the effects of the five shoot and root aqueous extract concentrations on the vegetable seeds, the method of Badmus and Afolayan (2012) was adopted with modifications. In triplicates, 25 seeds of each vegetable were placed evenly in $9 \mathrm{~cm}$ Petri dishes lined with two Whatman filter papers and moistened with the respective extract concentrations and distilled water in the control. The petri dishes were laid out in a Randomised Complete Block Design on a laboratory work bench under ambient temperature conditions (between 19 and $25^{\circ} \mathrm{C}$ ). The seeds were examined on a daily basis and considered germinated when the radicle was visible.

\section{Gas chromatography mass spectrometry (GC-MS)}

Using the modified method of Okoh and Afolayan (2011), $100 \mathrm{~g}$ of the fresh leaf and root samples of $S$. nigrum were subjected to a DRYDIST Milestone manufactured (2007) Solvent-free Microwave Extraction (SFME) Labstation apparatus for $30 \mathrm{~min}$. The extracted oil was kept in tightly sealed vial bottles in a refrigerator at $4{ }^{\circ} \mathrm{C}$ till further use. GC-MS analyses were performed on the Agilent 5977A MSD and 7890B GC System, Chemetrix (pty) Ltd; Agilent Technologies, DE (Germany) with a Zebron$5 \mathrm{MS}$ column (ZB-5MS $30 \mathrm{~m}$ x $0.25 \mathrm{~mm}$ x $0.25 \mathrm{um}$ ) (5\%-phenylmethylpolysiloxane) apparatus. The column and temperature conditions which were used were as follows: GC grade helium at a flow rate of $2 \mathrm{ml} / \mathrm{min}$ and splitless $1 \mu \mathrm{l}$ injections were used. The oven temperature, injector and source temperatures were set at 70,280 and $280^{\circ} \mathrm{C}$ respectively. The ramp settings were; $15^{\circ} \mathrm{C} / \min$ to $120^{\circ} \mathrm{C}$, then $10^{\circ} \mathrm{C} / \mathrm{min}$ to $180^{\circ} \mathrm{C}$, then $20^{\circ} \mathrm{C} / \mathrm{min}$ to $270^{\circ} \mathrm{C}$ and held for $3 \mathrm{~min}$.

\section{Identification of components}

The identification of the chemical constituents of the essential oil was determined by their GC retention times, percentage composition (Area \%) and retention indices. The interpretation and identification of their mass spectra was confirmed by mass spectral incorporated library. The identification was further confirmed by search using the National Institute of Standards and Technology (NIST) database (NIST/EPA/NIH mass spectral library 2014) and comparing with those of published data. 


\section{Statistical analysis}

Where applicable, the data were subjected to statistical analysis using MINITAB Release 12.22. A one way analysis of variance was used to compare seed germination as influenced by the extract concentration. Means were compared using Duncan's multiple range test. The means were treated as significantly different at $\mathrm{p}<0.05$.

\section{Results and discussion}

\section{Seed viability and germination}

Viability in the purchased cabbage, spinach and tomato seeds was 99, 92 and $83 \%$ respectively. In $S$. nigrum (belonging to the same family as tomatoes) seeds stored at room temperature in a period ranging from 1 to 9 years, Roberts and Lockett (1978) reported 99, 100, 96, 98, 91, 73, 27, 2 and 0\% viability. This indicates an inverse relationship between seed viability and time. However, the viability and germination results are in close agreement.

The effects of the aqueous extract of $S$. nigrum shoot on seed germination of cabbage; tomato and spinach are shown in Table 1.

Table 1. Percentage inhibition on germination of vegetable seeds as influenced by the aqueous extract of $S$. nigrum shoot extract

\begin{tabular}{cccc}
\hline & \multicolumn{3}{c}{ Vegetable seeds } \\
\cline { 2 - 4 } $10 \mathrm{mg} \mathrm{ml}^{-1}$ & Cabbage & Tomato & Spinach \\
$8 \mathrm{mg} \mathrm{ml}^{-1}$ & $97 \pm 0.58^{\mathrm{ab}}$ & $83 \pm 2.08$ & $65 \pm 3.06$ \\
$6 \mathrm{mg} \mathrm{ml}^{-1}$ & $97 \pm 0.58^{\mathrm{ab}}$ & $92 \pm 1.73$ & $80 \pm 1.00$ \\
$4 \mathrm{mg} \mathrm{ml}^{-1}$ & $100 \pm 0.00^{\mathrm{a}}$ & $92 \pm 0.58$ & $64 \pm 2.00$ \\
$2 \mathrm{mg} \mathrm{ml}^{-1}$ & $100 \pm 0.00^{\mathrm{a}}$ & $99 \pm 0.58$ & $72 \pm 4.58$ \\
Control & $96 \pm 0.00^{\mathrm{b}}$ & $89 \pm 0.79$ & $68 \pm 3.61$ \\
\hline
\end{tabular}

Values shown are $\mathrm{MEAN} \pm \mathrm{SD}$

Different letters down the same column represent significant differences at $\mathrm{p}<0.05$

The results indicate that the shoot extract did not significantly $(\mathrm{p}<0.05)$ affect the germination of tomato and spinach seeds. However, $2 \mathrm{mg} \mathrm{ml}^{-1}$ significantly lowered the germination of cabbage seeds although this was not significantly lower than $10 \mathrm{mg} \mathrm{ml}^{-1}$, the highest concentration. The root extract of $S$. nigrum did not significantly affect the germination of cabbage and spinach seeds but significantly hindered the germination of tomato seeds (Table 2). 
Table 2. Percentage inhibition on germination of vegetable seeds as influenced by the aqueous extract of $S$. nigrum root extract

\begin{tabular}{cccc}
\hline & \multicolumn{3}{c}{ Vegetable seeds } \\
\cline { 2 - 4 } $10 \mathrm{mg} \mathrm{ml}^{-1}$ & Cabbage & Tomato & Spinach \\
$8 \mathrm{mg} \mathrm{ml}^{-1}$ & $98 \pm 0.58$ & $13 \pm 1.73^{\mathrm{b}}$ & $42 \pm 1.16$ \\
$6 \mathrm{mg} \mathrm{ml}^{-1}$ & $96 \pm 0.58$ & $87 \pm 1.73^{\mathrm{a}}$ & $80 \pm 1.73$ \\
$4 \mathrm{mg} \mathrm{ml}^{-1}$ & $96 \pm 0.58$ & $62 \pm 4.62^{\mathrm{a}}$ & $60 \pm 3.31$ \\
$2 \mathrm{mg} \mathrm{ml}^{-1}$ & $98 \pm 0.58$ & $80 \pm 2.00^{\mathrm{a}}$ & $44 \pm 3.06$ \\
Control & $100 \pm 0.00$ & $87 \pm 0.00^{\mathrm{a}}$ & $40 \pm 4.58$ \\
\hline
\end{tabular}

Values shown are $\mathrm{MEAN} \pm \mathrm{SD}$

Different letters down the same column represent significant differences at $p<0.05$

The highest concentration $\left(10 \mathrm{mg} \mathrm{ml}^{-1}\right)$ significantly lowered tomato seed germination. The Mean Germination Time (Figs. 1 and 2) indicates that cabbage seeds germinated faster than spinach and tomato seeds. However, $10 \mathrm{mg} \mathrm{ml}^{-1}$ of both extracts significantly slowed down tomato seed germination time. Numerous allelopathic effects of $S$. nigrum on germination and growth have been performed on a wide range of crops and scantily on some important horticultural crops such as tomato, cabbage and onion. For example, Agarwal et al. (2002) reported that S. nigrum strongly inhibited plumule growth by $100 \%$ and radicle growth by $92 \%$ in some wheat cultivars. In the same study, $S$. nigrum strongly inhibited seedling growth as compared to other plants. S. nigrum extracts have also been reported to hinder the growth of chickpea as well as some tomato and onion cultivars (Kadioglu et al., 2004). Girija et al. (2008) as well as Marinov-Serafimov (2010) also reported some allelopathic effects of S. nigrum on some legumes. Although, studies on other species indicate that $S$. nigrum strongly hinders the growth of some important species, the present results indicate that this plant does not pose the same effects on some important horticultural crops such as tomato, cabbage and spinach.

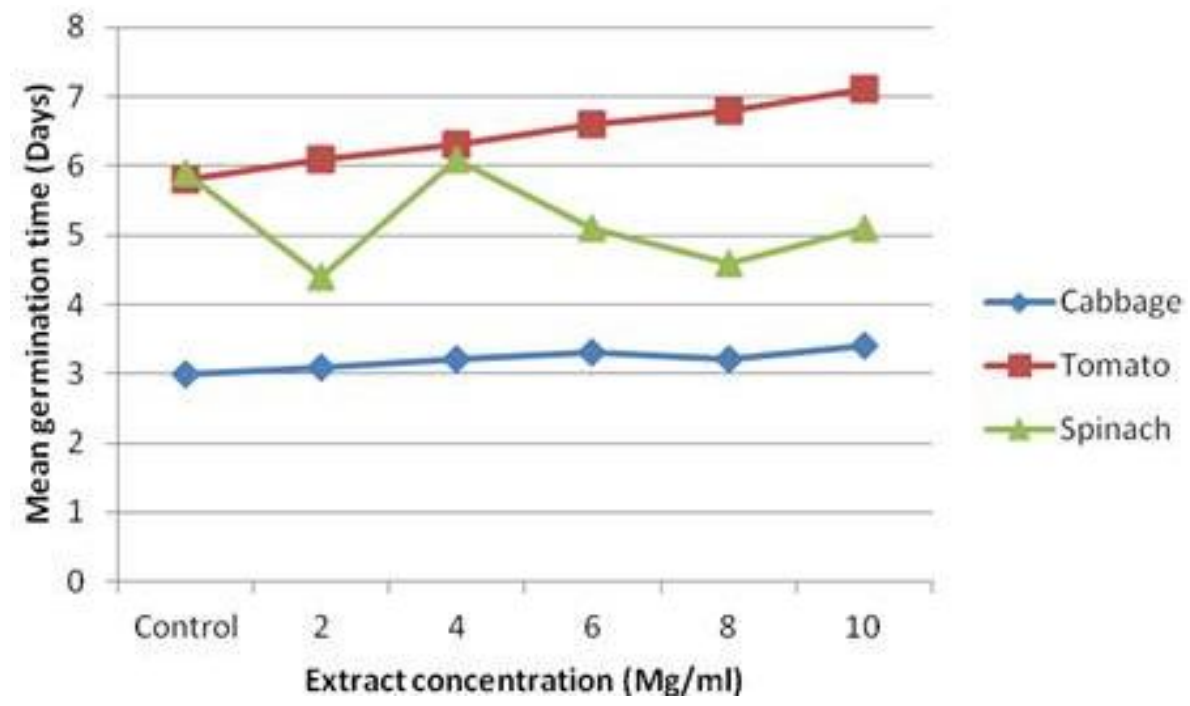

Figure 1. Effect of S. nigrum aqueous shoot extract on seed germination time of vegetables 


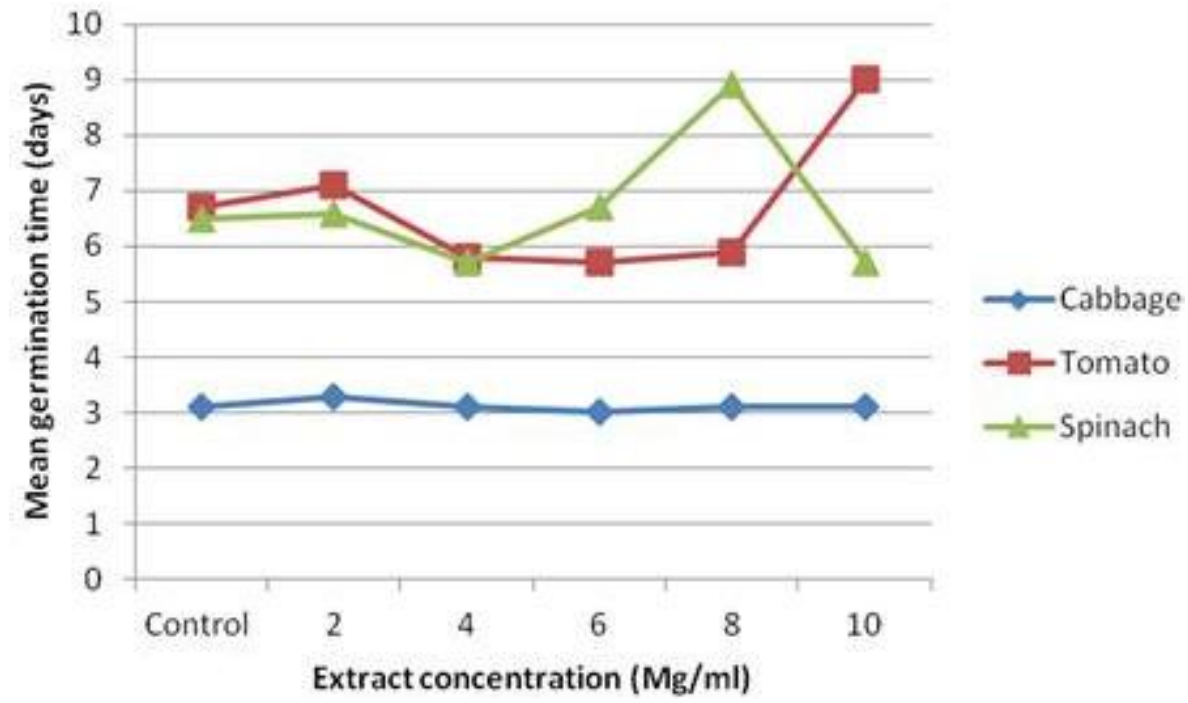

Figure 2. Effect of S. nigrum aqueous root extract on seed germination time of vegetables

\section{Essential oil compositions}

Both the shoot and root samples yielded a colourless oil with a pungent scent after extracting with the microwave. A total of 16 compounds were identified from the shoot oil extract (Table 3) and 12 were identified from the root oil extract (Table 4).

Table 3. Essential oil chemical composition of S. nigrum shoots

\begin{tabular}{|c|c|c|c|c|}
\hline Name & $\begin{array}{l}\text { Molecular } \\
\text { formula }\end{array}$ & RT & KI & $\begin{array}{c}\text { Area } \\
(\%)\end{array}$ \\
\hline$\alpha$-farnesene & $\mathrm{C}_{15} \mathrm{H}_{24}$ & 8.085 & 1580 & 2.57 \\
\hline .beta.-iso-Methyl ionone & $\mathrm{C}_{14} \mathrm{H}_{22} \mathrm{O}$ & 8.779 & 1673 & 2.63 \\
\hline 1-Benzothiazol-2-yl-3-(4-methyl-benzoyl)-thiourea & $\mathrm{C}_{16} \mathrm{H}_{13} \mathrm{~N}_{3} \mathrm{OS}_{2}$ & 7.893 & 2334 & 0.93 \\
\hline 2-[2-Thienyl]-4-acetyl quinoline & $\mathrm{C}_{15} \mathrm{H}_{11} \mathrm{NOS}$ & 7.736 & 1545 & 0.75 \\
\hline $\begin{array}{l}\text { 3-(4-Fluoro-phenyl)-4-methyl-2-(2, 2,2-trifluoro-1- } \\
\text { methoxycarbonyl-ethylidene)-2,3-dihydro-thiazole-5-carboxylic } \\
\text { acid ethyl ester }\end{array}$ & $\mathrm{C}_{17} \mathrm{H}_{15} \mathrm{~F}_{4} \mathrm{NO}_{4} \mathrm{~S}$ & 9.121 & 1596 & 2.02 \\
\hline Benzamide, 4-methoxy-N-[4-(1-methylcyclopropyl)phenyl]- & $\mathrm{C}_{18} \mathrm{H}_{19} \mathrm{NO}_{2}$ & 10.955 & 1729 & 0.66 \\
\hline Chola-5,22-dien-3-ol, (3.beta.,22Z)- & $\mathrm{C}_{24} \mathrm{H}_{38} \mathrm{O}$ & 8.477 & - & 1.91 \\
\hline Citronellol & $\mathrm{C}_{10} \mathrm{H}_{20} \mathrm{O}$ & 6.249 & 1368 & 11.98 \\
\hline Cyclobutanecarboxylic acid, 2-phenylethyl ester & $\mathrm{C}_{13} \mathrm{H}_{16} \mathrm{O}_{2}$ & 8.717 & 1690 & 2.71 \\
\hline Cyclohexanol, 2-methyl-5-(1-methylethenyl)- & $\mathrm{C}_{10} \mathrm{H}_{18} \mathrm{O}$ & 11.766 & 1920 & 5.84 \\
\hline Cyclopentaneethanol, 2-(hydroxymethyl)-.beta.,3-dimethyl- & $\mathrm{C}_{10} \mathrm{H}_{20} \mathrm{O}_{2}$ & 8.242 & 1567 & 0.98 \\
\hline Geraniol & $\mathrm{C}_{10} \mathrm{H}_{18} \mathrm{O}$ & 6.452 & 1388 & 3.76 \\
\hline Geranyl isobutyrate & $\mathrm{C}_{14} \mathrm{H}_{24} \mathrm{O}_{2}$ & 7.936 & 1594 & 1.36 \\
\hline Geranyl tiglate & $\mathrm{C}_{15} \mathrm{H}_{24} \mathrm{O}_{2}$ & 9.318 & 1703 & 3.53 \\
\hline p-Anisaldehyde 4-[1-adamantyl]-3-t hiosemicarbazone & $\mathrm{C}_{19} \mathrm{H}_{25} \mathrm{~N}_{3} \mathrm{OS}$ & 8.845 & 1506 & 1.92 \\
\hline Silane, chlorodimethyloctadecyl & $\mathrm{C}_{20} \mathrm{H}_{43} \mathrm{CLSi}$ & 8.440 & 1534 & 0.87 \\
\hline
\end{tabular}


In the shoots, the major compositions were Citronellol (11.98\%), Cyclohexanol, 2methyl-5-(1-methylethenyl) (5.84\%), Geraniol (3.76\%) and Geranyl tiglate (3.53\%). In the roots, Hexacosane (35.62\%), 1H-Indole, 1-methyl-2-phenyl (12.66\%) and Hexadecanal $(8.11 \%)$ were the major components. Four compounds, viz, $\alpha$-farnesene, Citronellol, Geraniol and Geranyl tiglate were identified in both the shoot and root extracts. Although some authors (Ogundajo et al., 2013; Sivakamasundari et al., 2013; Taherpour, et al., 2013; Aburjai et al., 2014; Huda et al., 2015) have reported various compounds in the leaves of $S$. nigrum, none have reported the findings of this current work. Aliero et al. (2006) reported the presence of Geraniol in the leaves of Solanum pseudocapsicum and this corresponds with what was found in both the shoot and root extracts of the present project.

Table 4. Essential oil chemical composition of S. nigrum roots

\begin{tabular}{ccccc}
\hline Name & Molecular formula & RT & KI & Area (\%) \\
\cline { 2 - 5 } 1,2,4-Benzenetricarboxylic acid, -dodecyl dimethyl ester & $\mathrm{C}_{23} \mathrm{H}_{34} \mathrm{O}_{6}$ & 13.008 & - & 0.43 \\
1H-Indole, 1-methyl-2-phenyl- & $\mathrm{C}_{15} \mathrm{H}_{13} \mathrm{~N}$ & 14.360 & 2207 & 12.66 \\
2-Phenylethyl tiglate & $\mathrm{C}_{13} \mathrm{H}_{16} \mathrm{O}_{2}$ & 8.711 & 1689 & 1.83 \\
$\alpha$-farnesene & $\mathrm{C}_{15} \mathrm{H}_{24}$ & 8.081 & 1579 & 2.38 \\
Citronellol & $\mathrm{C}_{10} \mathrm{H}_{20} \mathrm{O}$ & 6.249 & 1368 & 11.98 \\
Eicosane & $\mathrm{C}_{20} \mathrm{H}_{42}$ & 12.1911910 & 2.78 \\
Geraniol & $\mathrm{C}_{10} \mathrm{H}_{18} \mathrm{O}$ & 6.452 & 1388 & 3.76 \\
Geranyl tiglate & $\mathrm{C}_{15} \mathrm{H}_{24} \mathrm{O}_{2}$ & 9.318 & 1703 & 3.53 \\
Hexacosane & $\mathrm{C}_{26} \mathrm{H}_{54}$ & 11.305 & - & 35.62 \\
Hexadecanal & $\mathrm{C}_{16} \mathrm{H}_{32} \mathrm{O}$ & 9.380 & 1672 & 8.11 \\
Nonadecane & $\mathrm{C}_{19} \mathrm{H}_{4} \mathrm{O}$ & 10.335 & 1655 & 4.45 \\
Phthalic acid, 2-(1-adamantyl)ethyl methyl ester & $\mathrm{C}_{21} \mathrm{H}_{26} \mathrm{O}_{4}$ & 8.774 & - & 2.24 \\
\hline
\end{tabular}

\section{Conclusion}

The current study indicates that the viability and germination results are in close agreement. The shoot extract hindered the germination of cabbage while the root extract hindered that of tomato. Also, an increase in the shoot and root extract concentration slowed down the germination time of tomato seeds. However, the results indicate that $S$. nigrum does not pose a severe hindering effect on the germination of cabbage, spinach and tomato and as such possibilities of cultivating the wild vegetable alongside these exotic vegetables remain open. S. nigrum shoots and roots also possess a diverse range of chemicals in their essential oils. A total of 16 and 13 compounds were respectively identified by GC MS in the shoot and root extracts of the plant.

Acknowledgements. This project was funded by the Govan Mbeki Research and Development Centre of the University of Fort Hare, South Africa. 


\section{REFERENCES}

[1] Aburjai, T. A., Oun, I. M., Auzi, A. A., Hudaib, M. M. (2014): Volatile oil constituents of fruits and leaves of Solanum nigrum L. growing in Libya. - Journal of Essential Oil Bearing Plants 17(3): 397-404.

[2] Agarwal, A. R., Gahlot, A., Verma, R., Rao, P. B. (2002): Effect of weed extracts on seedling growth of some varieties of wheat. - Journal of Environmental Biology 23(1): 19-23.

[3] Aju, P. C., Labode, P., Uwalaka, R. E., Iwuanyanwu, U. P. (2013): The marketing potentials of indigenous leafy vegetables in Southeastern Nigeria. - Interntaional Journal of AgriScience 3(9): 667-677.

[4] Al-Mudaris, M. A. (1998): Notes on various parameters recording the speed of seed germination. - Der Tropenlandwirt - Journal of Agriculture in the Tropics and Subtropics/Beiträge zur tropischen Landwirtschaft und Veterinärmedizin (Archives: 1966-1999) 99(2): 147-154.

[5] Ataollahi, R., Dejam, M., Khaleghi, S. S. (2014): Phytotoxic effects of Eucalyptus globulus leaf extract on Solanum nigrum. - South Western Journal of Horticulture, Biology and Environment 5(1): 43-53.

[6] Atta, S., Diallo, A. B., Bakasso, Y., Sarr, B., Saadou, M., Glew, R. H. (2010): Microelement contents in Roselle (Hibiscus sabdariffa) at different growth stages. - African Journal of Food Agriculture, Nutrition and Development 10: 2615-2628.

[7] Badmus, A., Afolayan, A. J. (2012): Allelopathic potential of Arctotis arctotoides (L.f.) O. Hoffm aqueous extracts on the germination and seedling growth of some vegetables. African Journal of Biotechnology 11(47): 10711-10716.

[8] Baličević, R., Ravlić, M., Čuk, P., Šević, N. (2015): Allelopathic effect of three weed species on germination and growth of onion cultivars. (Unpublished: https://goo.gl/RNpFxR.)

[9] Edmonds, J. M., Chweya, J. A. (1997): Black Nightshade. Solanum Nigrum L. and Related Species. Promoting the Conservation and Use of Underutilised and Neglected Crops. 15. - Institute of Plant Genetics and Crop Plant Research, Gatersleben/International Plant Genetic Resources Institute, Rome.

[10] Flyman, M. V., Afolayan, A. J. (2008): Effect of plant maturity on the mineral content of the leaves of Momordica balsamina L. and Vigna unguiculata subsp. - Journal of Food Quality 31: 661-671.

[11] Fraenkel, G. S. (1959). The raison d'etre of secondary plant substances. - Science 129: 1466-1470.

[12] Gbile, A. Z. O., Adesina, S. K., Gbile, Z., Adesina, S. K. (1988): Nigerian Solanum species of economic importance. - Missouri Botanical Gardens 75(3): 862-865.

[13] Girija, G., Gowri, S. (2008): Allelopathic effect of Solanum nigrum on Pisum sativum, Eleusine coracana and Trigonella foenum Graecum. - Biomedical and Pharmacology Journal 1(1): 185-194.

[14] Huda, J., Ameera, O. H., Imad, H. H., Muhanned, A. K. (2015): Characterisation of alkaloid constitution and evaluation of antimicrobial activity of Solanum nigrum using gas chromatography mass spectrometry (GC-MS). - Journal of Pharmacognosy and Phytotherapy 7(4): 56-72.

[15] Kadioglu, I., Yanar, Y., Asav, U. (2004): Allelopathic effects of plant extracts against seed germination of some weeds. - Journal of Environmental Biology 26(2): 169-173.

[16] Khanh, T. D., Xuan, T. D., Chung, I. M. (2007): Rice allelopathy and the possibility for weed management. - Annals of Applied Biology 151: 325-339.

[17] Madisa, M. E., Tshamekang, M. E. (1997): Traditional African Vegetables: Conservation and Utilization of Indigenous Vegetables in Botswana. - In: Guarino, L. (ed.) IPGRI International Workshop on Genetic Resources of Traditional Vegetables in Africa: 
Conservation and Use, Nairobi, 29-31 August 1995. International Plant Genetic Resources Institute, Rome.

[18] Mahala, A. G., Amasiab, S. O., Monera, A., Elsadig, A. (2012): Effect of plant age on DM yield and nutritive value of some leguminous plants (Cyamopsis tetragonoloba, Lablab purpureus and Clitoria (Clitoria ternatea). - International Research Journal of Agricultural Science and Soil Science 2: 502-508.

[19] Marinov-Serafimov, P. (2010): Determination of allelopathic effect of some invasive weed species on germination and initial development of grain legume crops. - Journal Pesticides and Phytomedicine 25(3): 251-259.

[20] Maroyi, A. (2011): Potential role of traditional vegetables in household food security: A case study from Zimbabwe. - African Journal of Agricultural Research 6(26): 5720-5728.

[21] Mushita, A. (1997): Traditional African Vegetables: Traditional Vegetables in Zimbabwe - the NGO Agenda. - In: Guarino, L. (ed.) IPGRI International Workshop on Genetic Resources of Traditional Vegetables in Africa: Conservation and Use, Nairobi, 29-31 August 1995. International Plant Genetic Resources Institute, Rome.

[22] Odhav, B., Beekrum, S., Akula, U., Baijnath, H. (2007): Preliminary assessment of nutritional value of traditional leafy vegetables in KwaZulu-Natal, South Africa. Journal of Food Composition and Analysis 20: 430-435.

[23] Ogundajo, A. L., Oladosu, I. A., Ogunwande, I. A., Flamini, G., Owolabi, M. S. (2013): Study on the volatile constituents of Solanum nigrum var. virginicum L. from Nigeria. Asian Journal of Plant Science Research 3(1): 94-98.

[24] Okoh, O. O., Afolayan, A. J. (2011): The effects of hydrodistillation and solvent free microwave extraction methods on the chemical composition and toxicity of essential oils from the leaves of Mentha longifolia L. subsp. Capensis. - African Journal of Pharmacy and Pharmacology 5(22): 2478.

[25] Otusanya, O. O., Sokan-Adeaga, A. A., IIori, O. J. (2014): Allelopathic effect of the root exudates of Tithonia diversifolia on the germination, growth and chlorophyll accumulation of Amaranthus dubius L. and Solanum melongena L. - Research Journal of Botany 9(2): 13-23.

[26] Peters, P. (2000): Tetrazolium Testing Handbook, Contribution No. 29 to the Handbook on Seed Testing. - Prepared by the Tetrazolium Subcommittee of the Association of Official Seed Analysts. http://www.aosaseed.com/tzwebsite/2005pdf/2005Summary.pdf.

[27] Roberts, H. A., Lockett, P. M. (1978): Seed dormancy and field emergence in Solanum nigrum L. - Weed Research 18: 231-241.

[28] Sabh, A. Z. E., Ali, I. H. H. (2010): Allelopathic activity of nightshade (Solanum nigrum L.) on seedling growth of certain weeds and crops. - Annals of Agricultural Science 55(1): 87-94.

[29] Sadeghi, S., Ranavard, A., Ashrafi, Z. Y. (2010): Allelopathic effect of Helianthus annuus (Sunflower) on Solanum nigrum (Black nightshade) seed germination and growth in laboratory condition. - Journal of Horticulture, Science and Ornamental Plants 2(1): 32-37.

[30] Sivakamasundari, Ravishankar, Mariajancyrani, Chandramohan (2013): GC-MS analysis of chloroform extract of Solanum Nigrum leaf. Schol. - Academic Journal of Pharmacy 2(3): 268-273.

[31] Stamp, N. (2003): Out of the quagmire of plant defence hypotheses. - The Quarterly Review of Biology 78: 23-55.

[32] Taherpour, A., Khodaei, M. M., Ameen, B. A. H., Ghaitouli, M., Mahdizadeh, N., Amjadian, H. R., Larijani, K. (2013): Chemical composition analysis of the essential oil of Solanum nigrum L. by HS/SPME method and calculation of the biochemical coefficients of the components. - Arabian Journal of Chemistry 6(1): 8-11. 